\title{
EDIBLE WHEAT GLUTEN FILMS: DEVELOPMENT, MECHANICAL AND BARRIER PROPERTIES AND APPLICATION TO STRAWBERRIES (Fragaria Ananassa)
}

\author{
PATRICIA S. TANADA-PALMU * \\ CARLOS GROSSO **
}

\begin{abstract}
Films from wheat gluten were prepared with different $\mathrm{pH}$ values and concentrations of gluten, ethanol and glycerol. Their effects on oxygen and water vapor permeabilities, water solubility, tensile strength and percent elongation at break were evaluated using Response Surface Methodology. The lowest oxygen permeability would be expected at low concentrations of glycerol, gluten and ethanol. The mechanical properties were mainly affected by gluten and glycerol concentrations and the most resistant film was obtained at high gluten and low glycerol concentrations. Wheat gluten coating applied to fresh strawberries reduced weight and firmness losses during storage as compared to uncoated controls.
\end{abstract}

KEY WORDS: EDIBLE FILMS; WHEAT GLUTEN; STRAWBERRIES; PERMEABILITY; MECHANICAL PROPERTIES.

\section{INTRODUCTION}

Recently there has been considerable interest in edible films for foods (TANADA-PALMU \& GROSSO, 2002; PARK, 1999; AMARANTE \& BANKS, 2001). Such films can maintain food quality and improve stability and shelf life by retarding unwanted mass transfer in food products (MILLER \& $\mathrm{KROCHTA}, 1997)$, including to retard transport of gases $\left(\mathrm{O}_{2}, \mathrm{CO}_{2}\right)$ for fruits and vegetables, migration of moisture for dried and intermediate moisture foods, and migration of solutes for frozen foods (DONHOWE \& FENNEMA, 1992). They may also improve the recyclability of some packaging applications avoiding the disposal of non-renewable materials.

* Estudante de Doutorado, bolsa FAPESP, Departamento de Alimentos e Nutrição, Faculdade de Engenharia de Alimentos, Universidade Estadual de Campinas (UNICAMP), Campinas - SP, Brasil.

** Professor, Departamento de Alimentos e Nutrição, Faculdade de Engenharia de Alimentos, Universidade Estadual de Campinas (UNICAMP), Campinas- SP, Brasil. (e-mail (grosso@fea.unicamp.br). 
Polysaccharides, proteins and lipids can be used as edible film-forming agents (KESTER \& FENNEMA, 1986; GENNADIOS \& WELLER, 1991; AVENA-BUSTILLOS \& KROCHTA, 1993; McHUGH, AUJARD \& KROCHTA, 1994). In general, mechanical and barrier properties of biological films are highly associated with the polarity of film constituents (DEBEAUFORT, MARTIN-POLO \& VOILLEY, 1993). In protein-based films, the film-forming ability may be influenced by amino acid composition, their distribution and polarity which determine cross links between amino acids, hydrogen and dissulfide bondings (GENNADIOS \& WELLER, 1991). Due to the unique cohesive and elastic properties of gluten (WALL \& HUEBNER, 1981), good film-forming properties may be expected. Biodegradable and edible films from wheat proteins are useful in food packaging provided they are flexible, strong, heat sealable, and relatively transparent (RAYAS, HERNANDEZ \& NG, 1997). The mechanical and barrier properties of wheat gluten films have been studied (GENNADIOS et al., 1993; GONTARD, GUILBERT \& CUQ, 1993; CHERIAN et al., 1995). An edible wheat gluten film was developed and the effects of gluten, ethanol concentrations and $\mathrm{pH}$ of the film-forming solution on various film properties were evaluated (GONTARD, GUILBERT \& CUQ, 1992).

HERALD et al., (1995) compared wheat gluten films prepared at various $\mathrm{pH}$ values, as a result films prepared at $\mathrm{pH} 3.3$ showed higher water vapor permeability, presumibly due to the unfolding conformation of protein molecules and exposure of hydrophilic groups. Edible wheat gluten films were prepared with various amounts of glycerol (TANADA-PALMU, HELÉN \& HYVÖNEN, 2000). Films with low amounts of glycerol had lower water vapor and oxygen permeabilities, higher tensile strength and lower elongation at break. The objective of this work was the preparation of edible wheat gluten films and the evaluation of film forming conditions $\mathrm{(pH}$, concentrations of gluten, ethanol and glycerol) on the film properties (water solubility, oxygen and water vapor permeabilities and mechanical properties). Applications of such films as coatings for strawberries, a typical soft fruit having a high physiological post-harvest activity, were also investigated.

\section{MATERIALS AND METHODS}

\subsection{MATERIALS}

Vital wheat gluten (Rhodia, Campinas, Brazil), beeswax (Chemco, São Paulo, Brazil), glycerol (Merck, Darmstadt, Germany), ammonium hydroxide (Synth, São Paulo, Brazil), calcium chloride (Ecibra, São Paulo, 
Brazil), sodium chloride (Synth, São Paulo, Brazil), magnesium nitrate (Ecibra, São Paulo, Brazil), solid paraffin (Chemco, São Paulo, Brazil), fresh strawberries (Campinas free market).

\subsection{FILM PREPARATION}

The gluten concentration $(\mathrm{g} / 100 \mathrm{~mL}$ solution), ethanol concentration $(\mathrm{mL} /$ $100 \mathrm{~mL}$ solution), glycerol concentration ( $\mathrm{g} / 100 \mathrm{~mL}$ solution), and the $\mathrm{pH}$ of the solution (adjusted with ammonium hydroxide), used to prepare the films varied according to the values presented in Table 1. The film was prepared from a solution of gluten/absolute ethanol, ammonium hydroxide and distilled water. All components were mixed under magnetic stirring until the temperature of the mixture reached $70^{\circ} \mathrm{C}$ and the solution centrifuged at $5856 \mathrm{~g}$ for $6 \mathrm{~min}$ at room temperature. The film-forming solution was poured and spread evenly over a Teflon covered glass surface and dried at room temperature for $24 \mathrm{~h}$ (modified method from GONTARD, GUILBERT \& CUQ, 1993). The quantity of solution poured onto the surface was calculated to obtain a constant thickness of the dried film. All films used for experiments were equilibrated at $52 \%$ relative humidity $(\mathrm{RH})$, using a saturated solution of $\mathrm{Mg}\left(\mathrm{NO}_{3}\right)_{2}$ at $25^{\circ} \mathrm{C}$ for 48 hours $(\mathrm{h})$ before being tested.

\subsection{FILM THICKNESS}

Film thickness was measured using a micrometer (Model MDC-25M, Mitutoyo, MFG, Japan). The thickness of individual film samples was determined as an average of five measurements.

\subsection{WATER VAPOR PERMEABILITY}

The water vapor transmission rate of the films was determined gravimetrically at $25^{\circ} \mathrm{C}$ using a modified American Society for Testing and Materials (ASTM) Standard Method E-96 according to TANADA-PALMU, HELÉN \& HYVÖNEN, (2000). The samples, four replicates of each film, were conditioned for 2 days at $52 \% \mathrm{RH}$ before measurement. The water vapor permeability (WVP) was calculated according to the ASTM method.

\subsection{OXYGEN PERMEABILITY}

The oxygen transmission rates were determined using a modification of the ASTM Standard Method D 3985-81 with an Ox-Tran apparatus (Mocon, Inc., Minneapolis, USA) at $25^{\circ} \mathrm{C}$. The samples, two replicates of each 
film, were conditioned for 2 days at $52 \% \mathrm{RH}$ before measurement. The oxygen permeability (OP) was calculated by dividing the oxygen transmission rate by the oxygen pressure and multiplying by the mean thickness.

\subsection{TENSILE STRENGTH AND PERCENT ELONGATION AT BREAK}

Film tensile strength (TS) and percent elongation at break (ELO) were determined using a Texture Analyzer TA.XT2 (Stable Micro System, Surrey, UK), operated according to the ASTM Standard Method D $882-83\left(25^{\circ} \mathrm{C}\right.$ and $52 \% \mathrm{RH}$, initial grip separation $=50 \mathrm{~mm}$ and cross head speed $=100$ $\mathrm{mm} / \mathrm{min}$ ). The peak loads and extension at break were recorded for tested film specimens ( $100 \mathrm{~mm}$ long and $25.4 \mathrm{~mm}$ wide). The films were conditioned for 2 days at $52 \% \mathrm{RH}$ before measurement. Six specimens of each film were measured. The tensile strength and percent elongation at break were calculated according to the ASTM method.

\subsection{SOLUBILITY IN WATER}

The percent of solubility was the percentage of dry matter of the film solubilized after $24 \mathrm{~h}$ immersion in water. The percentage of initial dry matter of each film was determined at $105^{\circ} \mathrm{C}$ for $24 \mathrm{~h}$. Two discs of film ( $2 \mathrm{~cm}$ diameter) were cut, weighed, immersed in $50 \mathrm{~mL}$ of distilled water and slowly and periodically agitated for $24 \mathrm{~h}$ at $25^{\circ} \mathrm{C}$. The pieces of film were then taken out and dried $\left(105^{\circ} \mathrm{C}\right.$ for $\left.24 \mathrm{~h}\right)$ to determine the weight of dry matter which was not solubilized in water. The weight of dry matter solubilized was calculated by subtracting the weight of dry matter not solubilized from the weight of initial dry matter and reported as initial dry weight basis.

\subsection{STATISTICAL ANALYSIS}

The data were analyzed to fit the following second order equation to all dependent $Y$ variables:

$\mathrm{Y}=\mathrm{b}_{0}+\mathrm{b}_{1} \mathrm{X}_{1}+\mathrm{b}_{2} \mathrm{X}_{2}+\mathrm{b}_{3} \mathrm{X}_{3}+\mathrm{b}_{4} \mathrm{X}_{4}+\mathrm{b}_{12} \mathrm{X}_{1} \mathrm{X}_{2}+\mathrm{b}_{13} \mathrm{X}_{1} \mathrm{X}_{3}+\mathrm{b}_{14} \mathrm{X}_{1} \mathrm{X}_{4}+$ $b_{23} X_{2} X_{3}+b_{24} X_{2} X_{4}+b_{34} X_{3} X_{4}+b_{11} X_{1}^{2}+b_{22} X_{2}^{2}+b_{33} X_{3}^{2}+b_{44} X_{4}{ }^{2}$

Where $b_{n}$ are constant regression coefficients and $X_{1}, X_{2}, X_{3}$ coded 
independent variables. The Statistica ${ }^{\circledR}$ (Microsoft) program was used for the analysis of variance, regression coefficient calculation and response surfaces.

\subsection{APPLICATION OF THE EDIBLE FILM TO FRESH STRAWBERRIES}

The edible wheat gluten film was applied to coat fresh strawberries to evaluate the influence of the film on the weight and firmness losses of the product. Four treatments were effected to cover fresh strawberries with the gluten film. In treatment 1, fresh strawberries were dipped with pliers into the film-forming solution $(7.5 \mathrm{~g}$ gluten $+1.87 \mathrm{~g}$ glycerol $+45 \mathrm{~mL}$ ethanol/100 $\mathrm{mL}$ solution, $\mathrm{pH} 10$ ) at room temperature for 1 minute (min). In treatment 2, strawberries were dipped into the same film-forming solution as treatment 1 for $1 \mathrm{~min}$ and allowed to dry for $1 \mathrm{~h}$; then they were dipped again into the same solution for $1 \mathrm{~min}$ in order to form a bilayer gluten film over the strawberries. In treatment 3 , strawberries were treated as in treatment 2 , but the second layer was formed by dipping the strawberries into molten beeswax at $70^{\circ} \mathrm{C}$ for a few seconds. In treatment 4 (control), strawberries were dipped into distilled water for $1 \mathrm{~min}$. Strawberries were stored in the refrigerator for two weeks and during this time, the weight loss was followed and the firmness loss was registered by the Texture Analyzer.

\section{RESULTS AND DISCUSSION}

\subsection{STATISTICAL ANALYSIS AND RESPONSE SURFACES}

The experimental data presented on Table 1 and 2 shows the results of the analysis of variance for each of the dependent variables, with corresponding coefficients of multiple determination $\left(R^{2}\right)$ and $F$ values. The models for water vapor permeability $\left(Y_{2}\right)$ and solubility in water $\left(Y_{3}\right)$ showed a high lack of fit, considering there were no significant $p$ and $F$ values, indicating that data variations could not be adequately explained (THOMPSON, 1982). An investigation of the residual errors (difference between predicted and experimental $\mathrm{Y}$-variables values) indicated that $\mathrm{a}$ higher order model would be necessary to more adequately describe the data. However, these two models could be used for trend analysis. The models for oxygen permeability, tensile strength and percent elongation at break seemed adequate, with satisfactory $R^{2}$ and significant $p$ and $F$ values. 


\section{TABLE 1 - RESPONSES OF DEPENDENT VARIABLES TO THE FILM- FORMING CONDITIONS}

\begin{tabular}{|c|c|c|c|c|c|c|c|c|c|}
\hline \multirow[b]{2}{*}{ Films } & \multicolumn{4}{|c|}{ Independent variables $^{a}$} & \multicolumn{5}{|c|}{ Dependent variables } \\
\hline & $\mathrm{X}_{1}(\mathrm{pH})$ & $\mathrm{X}_{2}$ (glu) & $\mathrm{X}_{3}$ (gly) & $\mathrm{X}_{4}(\mathrm{et})$ & $\mathrm{Y}_{1}(\mathrm{OP})$ & $\mathrm{Y}_{2}(\mathrm{WVP})$ & $\mathrm{Y}_{3}(\mathrm{SOL})$ & $\mathrm{Y}_{4}(\mathrm{TS})$ & $\mathrm{Y}_{5}(\mathrm{ELO})$ \\
\hline 1 & $9.5(-1)$ & $6.0(-1)$ & $1.50(-1)$ & $32.5(-1)$ & 24.97 & 8.48 & 15.8 & 2.07 & 170.6 \\
\hline 2 & $10.5(+1)$ & $6.0(-1)$ & $1.50(-1)$ & $32.5(-1)$ & 21.03 & 8.67 & 13.3 & 1.98 & 143.5 \\
\hline 3 & $9.5(-1)$ & $9.0(+1)$ & $1.50(-1)$ & $32.5(-1)$ & 39.86 & 10.20 & 22.0 & 3.91 & 184.1 \\
\hline 4 & $10.5(+1)$ & $9.0(+1)$ & $1.50(-1)$ & $32.5(-1)$ & 41.02 & 8.61 & 22.7 & 5.25 & 215.3 \\
\hline 5 & $9.5(-1)$ & $6.0(-1)$ & $1.50(-1)$ & $57.5(+1)$ & 24.40 & 12.95 & 16.3 & 1.19 & 170.0 \\
\hline 6 & $10.5(+1)$ & $6.0(-1)$ & $1.50(-1)$ & $57.5(+1)$ & 26.79 & 11.61 & 16.1 & 1.33 & 160.5 \\
\hline 7 & $9.5(-1)$ & $9.0(+1)$ & $1.50(-1)$ & $57.5(+1)$ & 28.30 & 9.48 & 26.0 & 5.38 & 140.50 \\
\hline 8 & $10.5(+1)$ & $9.0(+1)$ & $1.50(-1)$ & $57.5(+1)$ & 36.95 & 8.58 & 11.1 & 7.17 & 138.60 \\
\hline 9 & $9.5(-1)$ & $6.0(-1)$ & $2.25(+1)$ & $32.5(-1)$ & 25.85 & 19.77 & 12.4 & 0.45 & 222.9 \\
\hline 10 & $10.5(+1)$ & $6.0(-1)$ & $2.25(+1)$ & $32.5(-1)$ & 33.20 & 14.89 & 24.1 & 0.42 & 163.4 \\
\hline 11 & $9.5(-1)$ & $9.0(+1)$ & $2.25(+1)$ & $32.5(-1)$ & 42.20 & 10.29 & 13.6 & 1.49 & 139.1 \\
\hline 12 & $10.5(+1)$ & $9.0(+1)$ & $2.25(+1)$ & $32.5(-1)$ & 42.30 & 9.63 & 12.4 & 1.65 & 175.1 \\
\hline 13 & $9.5(-1)$ & $6.0(-1)$ & $2.25(+1)$ & $57.5(+1)$ & 38.70 & 13.57 & 25.4 & 0.30 & 277.2 \\
\hline 14 & $10.5(+1)$ & $6.0(-1)$ & $2.25(+1)$ & $57.5(+1)$ & 28.30 & 12.48 & 27.0 & 0.42 & 282.8 \\
\hline 15 & $9.5(-1)$ & $9.0(+1)$ & $2.25(+1)$ & $57.5(+1)$ & 30.45 & 8.18 & 16.6 & 0.72 & 187.9 \\
\hline 16 & $10.5(+1)$ & $9.0(+1)$ & $2.25(+1)$ & $57.5(+1)$ & 36.40 & 8.19 & 17.4 & 0.70 & 273.9 \\
\hline 17 & $9.0(-2)$ & $7.5(0)$ & $1.87(0)$ & $45.0(0)$ & 46.58 & 12.69 & 23.3 & 1.03 & 263.9 \\
\hline 18 & $11.0(+2)$ & $7.5(0)$ & $1.87(0)$ & $45.0(0)$ & 34.76 & 8.53 & 20.9 & 1.70 & 232.6 \\
\hline 19 & $10.0(0)$ & $4.5(-2)$ & $1.87(0)$ & $45.0(0)$ & 29.16 & 9.61 & 13.5 & 0.37 & 302.3 \\
\hline 20 & $10.0(0)$ & $10.5(+2)$ & $1.87(0)$ & $45.0(0)$ & 34.47 & 8.65 & 16.2 & 1.39 & 282.0 \\
\hline 21 & $10.0(0)$ & $7.5(0)$ & $1.87(0)$ & $20.0(-2)$ & 41.93 & 11.07 & 26.5 & 0.88 & 234.1 \\
\hline 22 & $10.0(0)$ & $7.5(0)$ & $1.87(0)$ & $70.0(+2)$ & 49.68 & 14.91 & 22.5 & 0.87 & 196.8 \\
\hline 23 & $10.0(0)$ & $7.5(0)$ & $1.12(-2)$ & $45.0(0)$ & 35.82 & 5.72 & 17.4 & 2.36 & 184.1 \\
\hline 24 & $10.0(0)$ & $7.5(0)$ & $2.62(+2)$ & $45.0(0)$ & 38.64 & 10.46 & 12.7 & 0.55 & 336.4 \\
\hline $25(c)$ & $10.0(0)$ & $7.5(0)$ & $1.87(0)$ & $45.0(0)$ & 39.19 & 13.60 & 21.8 & 0.84 & 207.6 \\
\hline $26(c)$ & $10.0(0)$ & $7.5(0)$ & $1.87(0)$ & $45.0(0)$ & 41.25 & 12.56 & 16.3 & 1.22 & 216.5 \\
\hline $27(\mathrm{c})$ & $10.0(0)$ & $7.5(0)$ & $1.87(0)$ & $45.0(0)$ & 38.56 & 7.89 & 21.0 & 1.60 & 236.8 \\
\hline
\end{tabular}

${ }^{a}$ values between brackets are the coded symbols of the levels of the independent variables; (c) - central points of the plan; $\mathrm{X}_{1}(\mathrm{pH})$ - $\mathrm{pH}$ of the film-forming solution; $\mathrm{X}_{2}(\mathrm{glu})$ - gluten concentration $\left(\mathrm{g} / 100 \mathrm{~mL}\right.$ solution); $\mathrm{X}_{3}(\mathrm{gly})$ glycerol concentration $\left(\mathrm{g} / 100 \mathrm{~mL}\right.$ solution); $X_{4}$ (et) ethanol concentration ( $\mathrm{mL} / 100 \mathrm{~mL}$ solution); $\mathrm{Y}_{1}(\mathrm{OP})$ oxygen permeability $\left(\mathrm{cm}^{3} \mu \mathrm{m} / \mathrm{m}^{2} \mathrm{dkPa}\right)$; $\mathrm{Y}_{2}(\mathrm{WVP})$ water vapor permeability $\left(\mathrm{gmm} / \mathrm{m}^{2} \mathrm{dkPa}\right) ; \mathrm{Y}_{3}(\mathrm{SOL}) \quad$ solubility in water (\%); $\mathrm{Y}_{4}(\mathrm{TS})$ tensile strength $(\mathrm{MPa})$;

$Y_{5}($ ELO) percent elongation at break (\%).

The estimated partial regression coefficients $(\mathrm{RC})$, pure error $(\mathrm{PE})$ and level of significance $(p)$ for the five quadratic models and the results of significance tests on the coefficients are indicated in Table 2. The three variables (OP, TS and ELO) appeared to affect film properties. From the significant $p$ values, gluten (glu), glycerol (gly) and ethanol (et) 
concentrations of the film-forming solution were the most important factors influencing oxygen permeability and mechanical properties. The interaction between independent and dependent variables is represented by the threedimensional response surfaces (Figure 1 and 2) generated by the regression equations developed from the mathematical analysis.

\section{TABLE 2 - REGRESSION COEFFICIENTS, PURE ERROR AND LEVEL OF SIGNIFICANCE OF THE SECOND ORDER POLYNOMIALS ${ }^{\text {a FOR }} 5$ RESPONSE VARIABLES}

\begin{tabular}{|c|c|c|c|c|c|c|c|c|c|c|c|c|c|c|c|}
\hline & \multicolumn{3}{|c|}{$\begin{array}{c}\text { Oxygen permeability } \\
\left(\mathrm{Y}_{1}\right)\end{array}$} & \multicolumn{3}{|c|}{$\begin{array}{c}\text { Water permeability } \\
\left(Y_{2}\right)\end{array}$} & \multicolumn{3}{|c|}{ Solubility in water $\left(\mathrm{Y}_{3}\right)$} & \multicolumn{3}{|c|}{ Tensile strength $\left(\mathrm{Y}_{4}\right)$} & \multicolumn{3}{|c|}{ Elongation at break $\left(\mathrm{Y}_{5}\right)$} \\
\hline & $\mathrm{RC}$ & $\mathrm{PE}$ & $p$ & $\mathrm{RC}$ & $\mathrm{PE}$ & $p$ & $\mathrm{RC}$ & $\mathrm{PE}$ & $\mathrm{p}$ & $\mathrm{RC}$ & $\mathrm{PE}$ & $p$ & $\mathrm{RC}$ & $\mathrm{PE}$ & $P$ \\
\hline $\begin{array}{l}\text { constant } \\
\left(b_{0}\right)\end{array}$ & 39.67 & 0.81 & 0.0004 & 11.35 & 1.75 & 0.0231 & 19.70 & 1.71 & 0.0075 & 1.220 & 0.22 & 0.0308 & 220.30 & 8.64 & 0.0015 \\
\hline \multicolumn{16}{|l|}{ linear } \\
\hline $\mathrm{pH}\left(\mathrm{b}_{1}\right)$ & -1.03 & 0.57 & 0.2143 & -1.55 & 1.24 & 0.3386 & -0.73 & 1.21 & 0.6069 & 0.39 & 0.15 & 0.1254 & -0.09 & 6.11 & 0.9890 \\
\hline glu $\left(b_{2}\right)$ & 7.07 & 0.57 & 0.0065 & -2.60 & 1.24 & 0.1714 & -0.27 & 1.21 & 0.8464 & 1.68 & 0.15 & 0.0084 & -36.84 & 6.11 & 0.0264 \\
\hline gli $\left(b_{3}\right)$ & 3.31 & 0.57 & 0.0288 & 2.32 & 1.24 & 0.2020 & -0.32 & 1.21 & 0.8185 & -2.14 & 0.15 & 0.0052 & 80.74 & 6.11 & 0.0057 \\
\hline et $\left(b_{4}\right)$ & -0.39 & 0.57 & 0.5702 & 0.18 & 1.24 & 0.8971 & 0.97 & 1.21 & 0.5091 & -0.01 & 0.15 & 0.9886 & 10.19 & 6.11 & 0.2374 \\
\hline \multicolumn{16}{|l|}{ quadratic } \\
\hline $\begin{array}{l}\mathrm{pHx} \\
\mathrm{pH}\left(\mathrm{b}_{11}\right)\end{array}$ & -1.61 & 0.61 & 0.1183 & -0.11 & 1.32 & 0.9390 & 0.91 & 1.29 & 0.5517 & 0.41 & 0.16 & 0.1311 & -12.27 & 6.48 & 0.1874 \\
\hline $\begin{array}{l}\text { glu } x \\
\left.\text { glu(b } b_{22}\right)\end{array}$ & -6.04 & 0.61 & 0.0100 & -0.85 & 1.32 & 0.5833 & -2.71 & 1.29 & 0.1696 & 0.17 & 0.16 & 0.4192 & 9.17 & 6.48 & 0.2925 \\
\hline gli x gli $\left(b_{33}\right)$ & -3.33 & 0.61 & 0.0319 & -1.37 & 1.32 & 0.4064 & -0.32 & 1.29 & 0.1794 & 0.45 & 0.16 & 0.1103 & -6.77 & 6.48 & 0.4055 \\
\hline et $x$ et $\left(\mathrm{b}_{44}\right)$ & 0.96 & 0.61 & 0.2566 & 1.08 & 1.32 & 0.4996 & 2.11 & 1.29 & 0.2423 & 0.16 & 0.16 & 0.4250 & -29.17 & 6.48 & 0.0460 \\
\hline \multicolumn{16}{|l|}{ interactions } \\
\hline $\begin{array}{l}\mathrm{pHx} \\
\text { glu( }\left(\mathrm{b}_{12}\right)\end{array}$ & 2.56 & 0.70 & 0.0680 & 0.50 & 1.52 & 0.7746 & -3.15 & 1.48 & 0.1681 & 0.39 & 0.19 & 0.1757 & 30.31 & 7.48 & 0.0559 \\
\hline $\begin{array}{l}\mathrm{pHx} \\
\text { gli( }\left(\mathrm{b}_{13}\right)\end{array}$ & -0.66 & 0.70 & 0.4486 & -0.37 & 1.52 & 0.7941 & 3.72 & 1.48 & 0.1290 & -0.37 & 0.19 & 0.1918 & 9.34 & 7.48 & 0.3382 \\
\hline $\mathrm{pH} \times \mathrm{et}\left(\mathrm{b}_{14}\right)$ & 0.24 & 0.70 & 0.7655 & 0.45 & 1.52 & 0.8293 & -2.67 & 1.48 & 0.2136 & 0.08 & 0.19 & 0.7106 & 12.53 & 7.48 & 0.2360 \\
\hline $\begin{array}{l}\text { glu x } \\
\text { gli( }\left(b_{23}\right)\end{array}$ & -2.95 & 0.70 & 0.0523 & -2.45 & 1.52 & 0.8227 & -6.15 & 1.48 & 0.0537 & -1.52 & 0.19 & 0.0152 & 7.60 & 7.48 & 0.4164 \\
\hline $\begin{array}{l}\text { glu X } \\
\text { et(}\left(b_{24}\right)\end{array}$ & -5.80 & 0.70 & 0.0144 & -0.39 & 1.52 & 0.2488 & -2.35 & 1.48 & 0.2545 & 0.42 & 0.19 & 0.1584 & -53.48 & 7.48 & 0.0190 \\
\hline gli x et( $\left(b_{34}\right)$ & 0.09 & 0.70 & 0.9074 & -2.35 & 1.52 & 0.2619 & 3.52 & 1.48 & 0.1410 & -0.47 & 0.19 & 0.1384 & 86.28 & 7.48 & 0.0074 \\
\hline \%variability & & & & & & & & & & & & & & & \\
\hline $\mathrm{R}^{2}$ & \multicolumn{3}{|c|}{0.61639} & \multicolumn{3}{|c|}{0.72556} & \multicolumn{3}{|c|}{0.79565} & \multicolumn{3}{|c|}{0.76931} & \multicolumn{3}{|c|}{0.67388} \\
\hline $\mathrm{F}$ & & 1.38 & & & 2.27 & & & 3.34 & & & 2.86 & & & 3.39 & \\
\hline
\end{tabular}

${ }^{\mathrm{a}}$ Model on which $\mathrm{X}_{1}=\mathrm{pH}, \mathrm{X}_{2}=$ gluten concentration, $\mathrm{X}_{3}=$ glycerol concentration, $\mathrm{X}_{4}=$ ethanol concentration of the film -form ing solution is:

$Y=b_{0}+b_{1} X_{1}+b_{2} X_{2}+b_{3} X_{3}+b_{4} X_{4}+b_{12} X_{1} X_{2}+b_{13} X_{1} X_{3}+b_{14} X_{1} X_{4}+b_{23} X_{2} X_{3}+b_{24} X_{2} X_{4}+b_{34} X_{3} X_{4}+$

$b_{11} X_{1}^{2}+b_{22} X_{2}^{2}+b_{33} X_{3}^{2}+b_{44} X_{4}^{2}$

$R C$ : regression coefficients.

PE: pure error.

$\mathrm{p}$ : level of significance.

F from table:2.62.

Bold numbers: significant at $5 \%$ level. 


\subsection{WATER VAPOR PERMEABILITY}

The water vapor permeability should be as low as possible since an edible film or coating should retard moisture transfer between the food and the environment, or between two components of a heterogeneous food product (GONTARD, GUILBERT \& CUQ, 1992).

According to BANKER (1966), plasticizers are added to films to reduce brittleness, increase toughness, strength, tear and impact resistance and impart flexibility. Usually the addition of the plasticizer increase gas, water vapor and solute permeabilities and decrease the tensile strength of the films. From the results (Table 1), water vapor permeability (WVP) increased with glycerol concentration in accordance with GONTARD, GUILBERT \& CUQ, (1993); PARK et al., (1994a) and TANADA-PALMU, HELÉN \& HYVÖNEN, (2000). The plasticizers achieve such changes probably through interactions between plasticizer and polymer and the reduction of cumulative intermolecular forces along polymer chains, leading to "softening" of the film structure (GENNADIOS et al., 1993). Additionally this could be explained by the modifications of the protein structure, which might become less dense, and by the hydrophilicity of glycerol, which favors adsorption and desorption of water molecules (GONTARD, GUILBERT \& CUQ, 1993). Thus, the lowest WVP was obtained from film 23 , the one with the lowest glycerol concentration.

Increasing the ethanol concentration of the film-forming solution increased WVP. At high ethanol concentration the film became heterogeneous and this could explain the feasibility of water transmission.

\subsection{OXYGEN PERMEABILITY}

Good oxygen barrier properties of edible films can be used in food packaging and preservation. As an example, coating foods susceptible to lipid oxidation with protein films, in combination with an external conventional moisture barrier package seems to be possible. Oxygen permeability of all the wheat gluten films were similar to the values obtained by PARK \& CHINNAN, (1990) for zein:glycerin films $\left(13.0-44.9 \mathrm{~cm}^{3} \mu \mathrm{m} / \mathrm{m}^{2} \mathrm{dkPa}\right)$ and gluten:glycerin films $\left(9.6-24.2 \mathrm{~cm}^{3} \mu \mathrm{m} / \mathrm{m}^{2} \mathrm{dkPa}\right)$ at $30^{\circ} \mathrm{C}$ and $0 \% \mathrm{RH}$. Oxygen permeability of all films was low, maybe due to their polar nature and linear structure, which leads to a high cohesive energy density and a low free volume (TANADA-PALMU, HELÉN \& HYVÖNEN, 2000). 
The shape of the response surfaces (Figures $1 \mathrm{~A}$ and $2 \mathrm{~A}$ ) was characteristic of the interaction between gluten, glycerol and ethanol concentrations and showed that the lowest oxygen permeability value would be expected with low concentrations of these three variables.

\section{FIGURE 1 - RESPONSE SURFACE FOR THE EFFECT OF GLUTEN AND GLYCEROL CONCENTRATIONS OF THE FILM-FORMING SOLUTION ON OXYGEN PERMEABILITY (A), TENSILE STRENGTH (B) AND ELONGATION AT BREAK (C)}

A

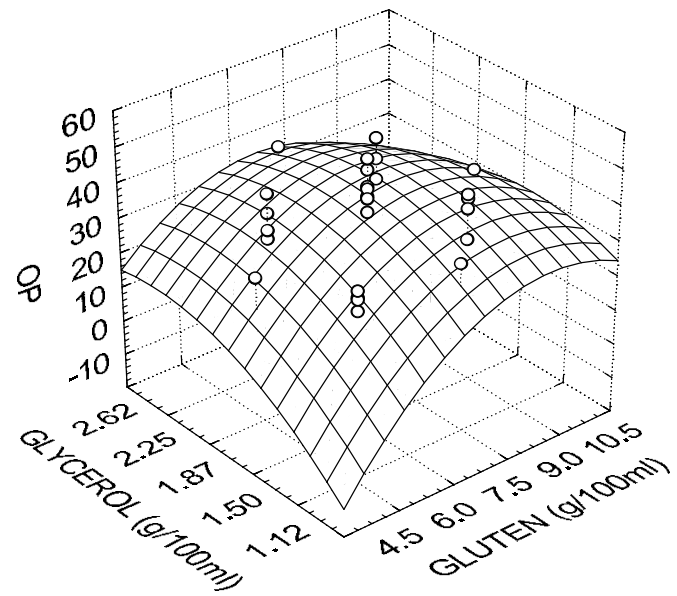

B

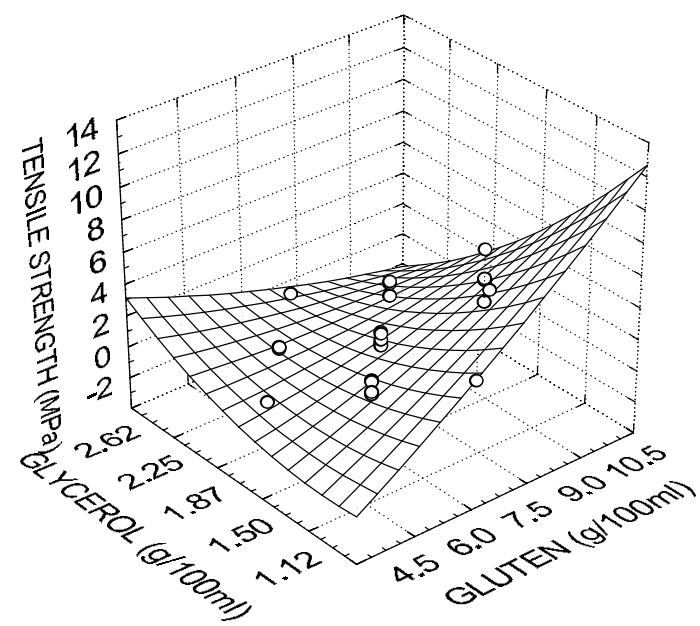


C

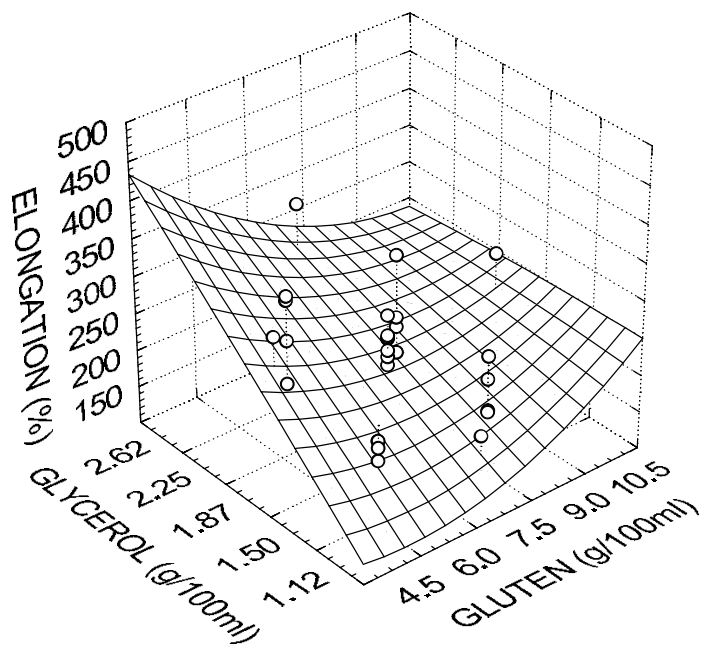

FIGURE 2 - RESPONSE SURFACE FOR THE EFFECT OF GLUTEN AND ETHANOL CONCENTRATIONS OF THE FILM-FORMING SOLUTION ON OXYGEN PERMEABILITY (A), TENSILE STRENGTH (B) AND ELONGATION AT BREAK (C)

A

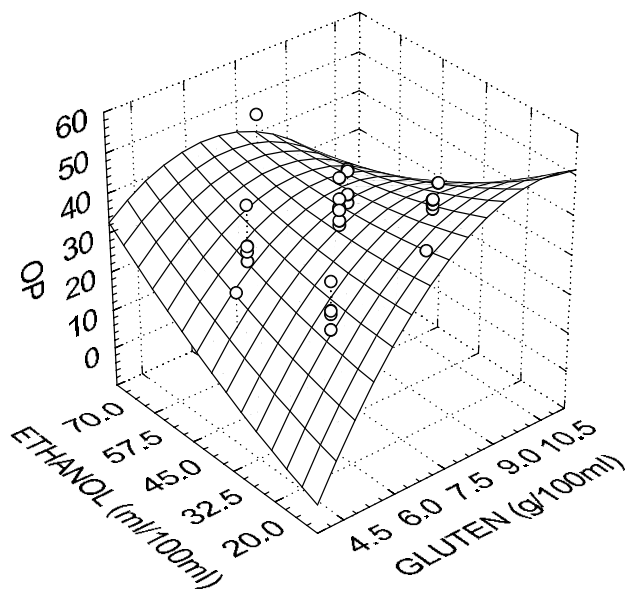


B

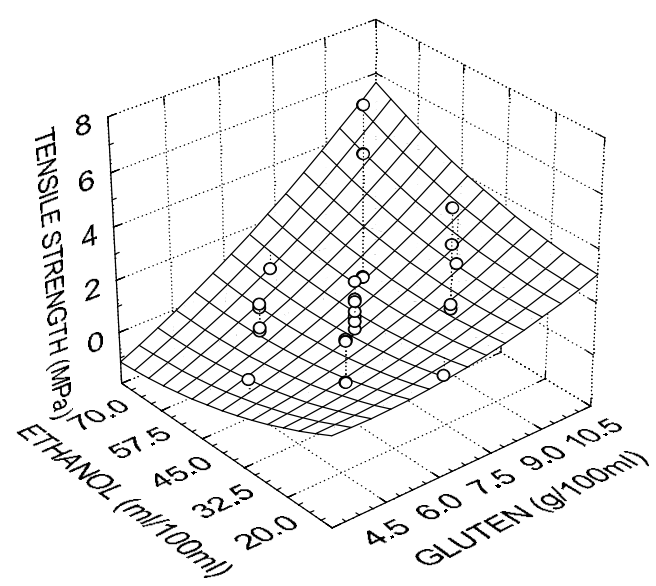

C

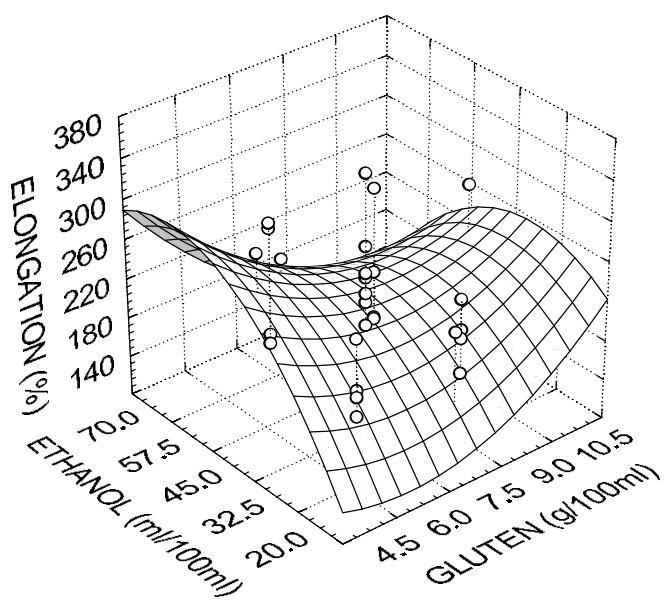

\subsection{MECHANICAL PROPERTIES}

An edible film should be resistant in order to withstand the manipulation during its application and to maintain its integrity and also its barrier properties. Tensile strength decreased and percent elongation at break increased with an increase in glycerol concentration (Figures 1B and 1C), in accordance with TANADA-PALMU, HELÉN \& HYVÖNEN, (2000). This similar behavior has been reported for other films (PARK et al., 1993; McHUGH \& KROCHTA, 1994; GENNADIOS et al., 1996). Unplasticized 
gluten film has low flexibility due to highly cooperative protein-protein interaction, mainly because of the high glutamine content which is responsible for numerous hydrogen bonds between protein chains. Glycerol is a small hydrophilic molecule which could be inserted between protein chains. With glycerol in the protein network the distance between protein chains was increased and direct interactions were reduced.

The response surface showed that at high gluten concentrations, films became more resistant with a high tensile strength (Figures 1B and 2B). Percent elongation at break decreased as gluten concentration increased and the concentration of ethanol decreased (Figures $1 \mathrm{C}$ and $2 \mathrm{C}$ ). The mechanism to form a resistant film could involve a higher number and/or a better localization of bonds between protein chains. During the drying of the film-forming solution, ethanol and ammonium hydroxide were evaporated, allowing the formation of bonds between protein chains. During this stage, the proximity of protein chains induced by high gluten concentrations could form such cross-bonds. During film formation, polymerization occurs through intermolecular disulfide, hydrophobic and hydrogen bondings (WALL \& BECKWITH, 1969). An alkaline environment and heating are necessary to denature the gluten protein, thus disrupting protein structure, breaking existing disulfide intramolecular bonds and exposing sulphydryl and hydrophobic groups, making them available for bonding. The cleavage of disulfide bonds results in polypeptide chains with lower molecular weights, destroying elasticity and cohesiveness of gluten. Upon casting and drying, sulphydryl groups reform disulfide bonds by air oxidation, which leads the film structure (GENNADIOS et al., 1993). Similar observations (MUNOZ, PANGBORN \& NOBLE, 1986; BANKER, 1966; GUILBERT \& BIQUET, 1989) have been made with protein (gelatin) gels which had lower puncture forces at low protein concentration.

\subsection{SOLUBILITY IN WATER}

Water resistance is an important property of edible films for applications in food protection, where water activity is high, or when the film must be in contact with water during processing of the coated food to avoid exudation of fresh or frozen products. Therefore, edible films with high water solubility may be required, for example, to contain premeasured portions which will be dissolved in water or in hot food (GUILBERT \& BIQUET, 1989). Solubility in water was low for all films, compared to zein films (solubility about $90 \%$, F5000, Freeman Industries, NY) which disintegrate easily in water. 


\subsection{APPLICATION OF WHEAT GLUTEN TO STRAWBERRIES}

Edible wheat gluten coatings were applied in order to reduce moisture and firmness losses during storage. Moisture and firmness losses, in terms of $\%$ weight loss and rupture force $(\mathrm{N})$, between controls and coated products during two weeks of storage are illustrated in Figure 3.

\section{FIGURE 3 - WEIGHT (A) AND RUPTURE FORCE (B) OF GLUTEN COATED AND UNCOATED STRAWBERRIES DURING STORAGE}
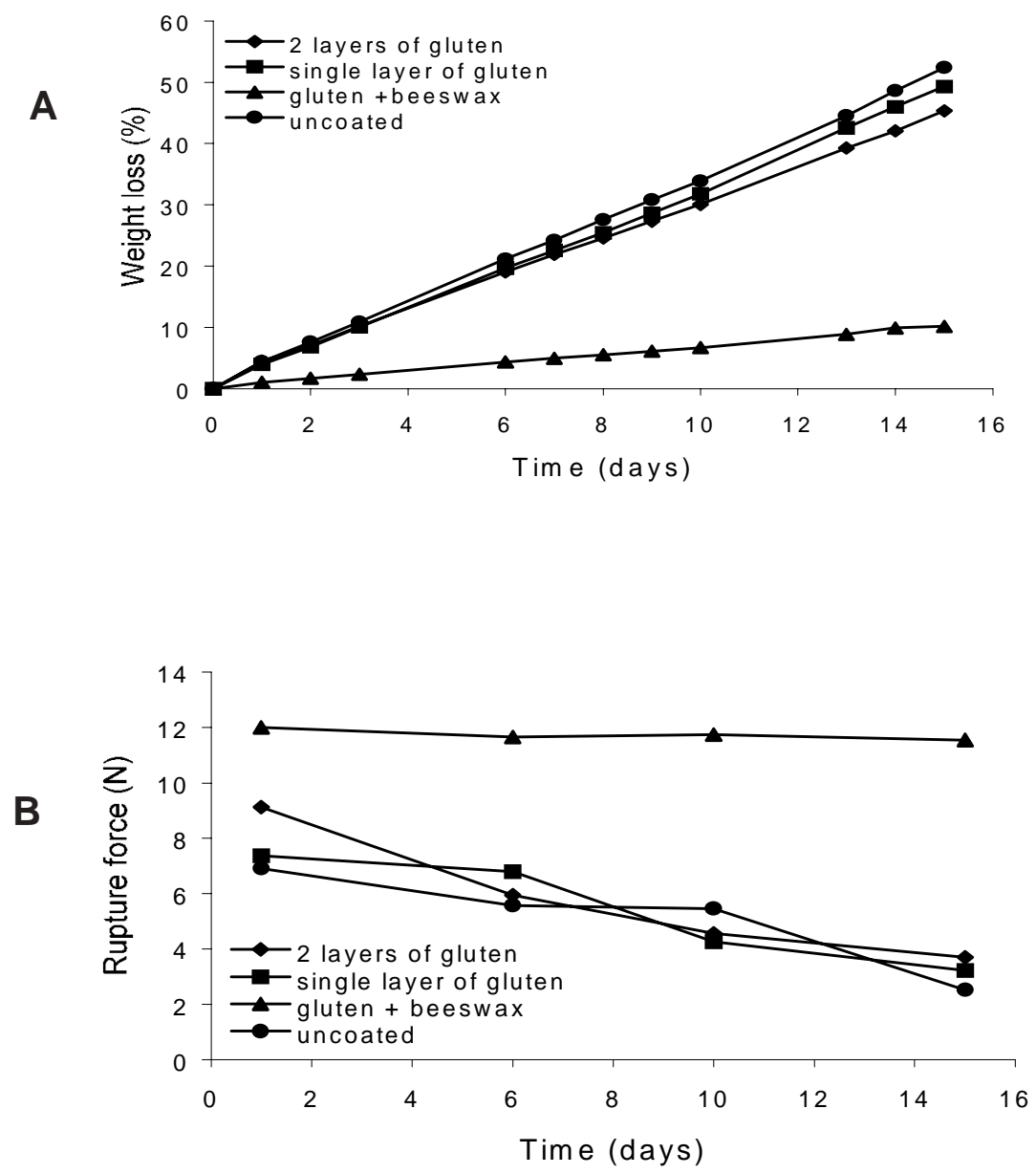
Uncoated strawberries lost weight faster and showed higher firmness loss than the coated samples with wheat gluten and beeswax during storage. However, there was no great difference in weight and firmness losses of the gluten coated strawberries (1 or 2 layers) and the controls. The strawberries coated with a bilayer coating, dipped in wheat gluten filmforming solution and with a second layer of beeswax, had relatively low weight and firmness losses. Texture modifications in fruits and vegetables are related to the composition of the cell wall, enzyme activity, metabolic changes and water content. The rate and extension of firmness loss during ripening of soft fruits like strawberries is the main factor which determines fruit quality and post-harvest shelf life. According to MANNING, (1993), fruit softening is attributed to the degradation of cell wall components due to specific enzyme activity.

The wheat gluten coating reduced moisture and firmness losses from strawberries. TANADA-PALMU, HELÉN \& HYVÖNEN, (2000) showed that gluten coating reduced weight loss of cherry tomatoes and sharon fruits and a bilayer coating of gluten and beeswax significantly reduced the weight loss of cheese cubes comparing to a single layer of gluten coating. PARK, CHINNAN \& SHEWFELT, (1994b) reported that a corn zein film behaved similarly with tomatoes. LERDTHANANGKUL \& KROCHTA, (1996) observed that a mineral-oil-based coating reduced moisture loss from green bell peppers. Starch-based films reduced moisture loss from strawberries (GARCíA, MARTINO \& ZARITZKY, 1998a,b).

A bilayer coating of wheat gluten and beeswax showed the best results to keep the quality of strawberries during storage. Thus, a second layer of lipid is necessary to improve the water vapor barrier capacity of the wheat gluten coatings in order to control the moisture and firmness losses from coated products.

\section{CONCLUSION}

Wheat gluten can be used as a source of protein-based biodegradable films and coatings. Response surface methodology seemed to be an effective tool for studying film-formation conditions. Concentrations of gluten, glycerol and ethanol influenced oxygen permeability and mechanical properties (tensile strength and percent elongation at break) of the gluten films. Gluten based coatings could be used to protect perishable foods such as strawberries. However, an additional lipid layer is necessary to reduce moisture and firmness losses of the coated products. Possibilities of improving wheat gluten film properties and evaluating new applications of the gluten coating should be explored. 


\section{Resumo}

FILMES COMESTÍVEIS DE GLÚTEN DE TRIGO: DESENVOLVIMENTO, PROPRIEDADES DE BARREIRA E MECÂNICAS E APLICAÇÃO NA COBERTURA DE MORANGOS (Fragaria Ananassa)

Filmes de glúten de trigo foram preparados em diferentes valores de $\mathrm{pH}$ e concentrações de glúten, etanol e glicerol. Seus efeitos sobre permeabilidade ao vapor de água e oxigênio, solubilidade em água, força de tensão e porcentagem de elongação foram avaliados usando-se a Metodologia de Superfície de Resposta. Menor permeabilidade ao oxigênio foi observada em menores concentrações de glicerol, glúten e etanol. As propriedades mecânicas foram principalmente afetadas pelas concentrações de glúten e glicerol e o filme mais resistente foi obtido quando maior concentração de glúten e menor de glicerol foram utilizadas. Coberturas de glúten de trigo aplicadas em morangos frescos reduziram as perdas de firmeza e de peso durante a estocagem em comparação com controle não revestido.

PALAVRAS-CHAVES: FILMES COMESTÍVEIS; GLÚTEN DE TRIGO; MORANGOS; PERMEABILIDADE; PROPRIEDADES MECÂNICAS.

\section{REFERENCES}

1 AMARANTE C.; BANKS N. H. Postharvest physiology and quality of coated fruits and vegetables. Horticultural Reviews, v.26, p. 161238, 2001.

2 ASTM. Standard test methods for water vapor transmission of materials: method E-96. In: ANNUAL book of ASTM standards. Conshohocken, PA, 1980.

3 ASTM. Standard test methods for gas transmission rate of plastic film and sheeting: method D 3985-81. In: ANNUAL book of ASTM standards. Conshohocken, PA, 1980.

4 ASTM. Standard test methods for tensile properties of thin plastic sheeting: method D 882-83. In: ANNUAL book of ASTM standards. Conshohocken, PA, 1980.

5 AVENA-BUSTILLOS, R. J.; KROCHTA J. M. Water vapor permeability of caseinate-based edible films as affected by $\mathrm{pH}$, calcium crosslinking and lipid content. Journal of Food Science, v.58, n. 4, p. 904-907, 1993.

6 BANKER, G. S. Film coating theory and practice. Journal of Pharmacy Science v. 55, p. 81-89, 1966.

7 CHERIAN, G.; GENNADIOS, A.; WELLER, C. L.; CHINACHOTI, P. Thermomechanical behavior of wheat gluten films: effect of sucrose, 
glycerin, and sorbitol. Cereal Chemistry, v. 72, p. 1-6, 1995.

8 DEBEAUFORT, F.; MARTIN-POLO, M.; VOILLEY, A. Polarity, homogeneity and structure affect water vapor permeability of model edible films. Journal of Food Science, v.58, p. 436-434, 1993.

9 DONHOWE, G.; FENNEMA, O. The effect of relative humidity gradient on water vapor permeance of lipid and lipid-hydrocolloid bilayer films. Journal of American Chemistry Society, v.6, p.1081-1087, 1992.

10 GARCÍA, M. A.; MARTINO, M. N.; ZARITZKY, N. E. Starch-based coatings: effect on refrigerated strawberry (Fragaria ananassa) quality. Journal of the Science of Food and Agriculture, v.76, p. 411420, 1998a.

11 GARCÍA, M. A.; MARTINO, M. N.; ZARITZKY, N. E. Plasticized starch-based coatings to improve strawberry (Fragaria ananassa) quality and stability. Journal of Agriculture and Food Chemistry, v.46, p. 3758-3767, 1998b.

12 GENNADIOS, A.; WELLER, C. L. Edible films and coatings from soymilk and soy protein. Cereal Foods World, v.36, p. 1004-1009, 1991.

13 GENNADIOS, A.; BRANDENBURG, A. H.; WELLER, C. L. ; TESTIN, R. F. Effect of $\mathrm{pH}$ on properties of wheat gluten and soy protein isolate films. Journal of Agriculture and Food Chemistry, v.41, p.1835-1839, 1993.

14 GENNADIOS, A.; WELLER, C. L.; HANNA, M. A.; FRONING, G. $W$. Mechanical and barrier properties of egg albumen films. Journal of Food Science, v.61, n. 3, p. 585-589, 1996.

15 GONTARD, N.; GUILBERT, S.; CUQ, J. L. Edible wheat gluten films: influence of the main process variables on film properties using response surface methodology. Journal of Food Science, v.57, n.1, p. 190-199, 1992.

16 GONTARD, N.; GUILBERT, S.; CUQ, J. L. Water and glycerol as plasticizer affect mechanical and water vapor barrier properties of an edible wheat gluten film. Journal of Food Science, v.58, n.1, p. 206-211, 1993.

17 GUILBERT, S.; BIQUET, B. Les films et enrobage comestibles. In L'EMBALLAGE des denrées alimentaires de grande consommation. Paris: Lavoisier, April 1989. p.320. (Technique et Documentation). 
18 HERALD, T. J.; GNANASAMBANDAM, R.; MCGUIRE, B. H.; HACHMEISTER, K. A. Degradable wheat gluten films: preparation, properties and aplications. Journal of Food Science, v.60, n.5, p. 1147-1150, 1156, 1995.

19 KESTER, J. J. ; FENNEMA, O. Edible films and coatings: a review. Food Technology, v.40 n.12, p. 47-59, 1986.

20 LERDTHANANGKUL, S. ; KROCHTA, J. M. Edible coating effects on postharvest quality of green bell peppers. Journal of Food Science, v.61, n.1, p. 176-179, 1996.

21 MANNING, K. Soft fruits. In BIOCHEMISTRY of fruit ripening. London, UK: Chapman \& Hall, 1993. p. 347-373.

22 MCHUGH, T. H.; AUJARD, J. F. ; KROCHTA, J. M. Plasticized whey protein edible films: water vapor permeability properties. Journal of Food Science, v.59, p. 416-419, 423, 1994.

23 MCHUGH, T. H. ; KROCHTA, J. M. Sorbitol vs glycerol plasticized whey protein edible films: Integrated oxygen permeability and tensile property evaluation. Journal of Agriculture and Food Chemistry, v.42, n.4, p.841-845, 1994.

24 MILLER, K. S. ; KROCHTA, J. M. Oxygen and aroma barrier properties of edible films: a review. Trends in Food Science and Technology, v.8, p.228-237, 1997.

25 MUNOZ, A. M.; PANGBORN, R. M. ; NOBLE, A. C. Sensory and mechanical attributes of gel texture. 1. Effect of gelatin concentration. Journal of Texture Studies, v.17, p.1, 1986.

26 PARK, H.J.; CHINNAN, M.S. Properties of edible coatings for fruits and vegetables. In: INTERNATIONAL WINTER MEETING, American Society of Agricultural Engineers, 1990 December 18-21, Chicago, IL: ASAE, 1990. (Paper n. 90-6510).

27 PARK, H. J.; WELLER, C. L.; VERGANO, P. J.; TESTIN, R. F. Permeability and mechanical properties of cellulose-based edible films. Journal of Food Science, v.58, p.1361-1364, 1993.

28 PARK, H. J.; BUNN, J. M.; WELLER, C. L.; VERGANO, P. J.; TESTIN, R. F. Water vapor permeability and mechanical properties of grain protein-based films as affected by mixtures of polyethylene glycol and glycerin plasticizers. Transactions of the ASAE, v.37, p.1281-1285, 1994a. 
29 PARK, H.J.; CHINNAN, M.S.; SHEWFELT, R.L. Edible coating effects on storage life and quality of tomatoes. Journal of Food Science, v.59, n.3, p.568-570, 1994b.

30 PARK, H. J. Development of advanced edible coatings for fruits. Trends in Food Science and Technology, v.10, p. 254-260, 1999.

31 RAYAS, L. M.; HERNANDEZ, R. J.; NG, P. K. W. Development and characterization of biodegradable/edible wheat protein films. Journal of Food Science, v.62, n.1, p.160-162, 189, 1997.

32 STASOFT. Statistica: kernel release 5.5 A. USA, 1984-2000.

33 TANADA-PALMU, P. S.; HELÉN, H.; HYVÖNEN, L. Preparation, properties and applications of wheat gluten edible films. Agriculture and Food Science in Finland, v.9, p.23-35, 2000.

34 TANADA-PALMU, P. S.; GROSSO, C. R. F. Wheat gluten composite and bilayer edible films: effect of lipid addition. In: RESEARCH advances in food agriculture and chemistry. Kerala, Índia: Global Research Network, 2002. p. 53-60.

35 THOMPSON, D. R. Response surface experimentation. Journal of Food Process and Preservation, v.6, p. 155, 1982.

36 WALL, J. S.; BECKWITH, A. C. Relationships between structure and rheological properties of gluten properties. Cereal Science Today, v.14, n.1, p.16-21, 1969.

37 WALL, J. S.; HUEBNER, F. R. Adhesion and cohesion. In: PROTEIN functionality in foods. Washington, D.C: American Chemical Society, 1981. p. 111.

\section{ACKNOWLEDGEMENTS}

We thank FAPESP (Fundação de Amparo à Pesquisa do Estado de São Paulo) for the scholarship conceded to P.S. Tanada-Palmu. 